This is the author copy of a peer-reviewed paper published in the Quarterly Journal of Engineering Geology and Hydrogeology, 39, 293-302. Minor differences may exist between this and the published version. Please respect the copyright of the journal and that of the authors.

\title{
The application of 3D geological modelling to aquifer recharge assessments in an urban environment
}

\author{
Lelliott, M R,* Bridge, D McC, Kessler, H, Price, S J. (British Geological Survey, \\ Keyworth, NG12 5GG, UK) \\ *corresponding author \\ Seymour, K J. (Environment Agency North West Region, Richard Fairclough \\ House, Warrington, WA4 1HG)
}

\begin{abstract}
The development of an attributed 3D model of the Quaternary deposits across $75 \mathrm{~km}^{2}$ of central Manchester and Salford is providing a basis for new types of applied (thematic) outputs. Proprietary software designed specifically for use in Quaternary sequences has been used to construct a model of the glacial and post-glacial sequences in an area now undergoing rapid regeneration. The potential of the model to deliver information relevant to a range of practical applications is illustrated by an urban groundwater case study centred on the industrial area of Trafford Park. The sensitivity of the Permo-Triassic sandstone bedrock aquifer to pollution and the extent to which recharge may occur have been analysed through detailed characterisation of the underlying superficial deposits. Potential hydrogeological pathways from ground surface to the sandstone are identified,
\end{abstract}


and thematic outputs show the importance of the Manchester Ship Canal and related waterways as potential sources of recharge and pollution of the bedrock aquifer. The move towards 3D modelling of the shallow subsurface provides flexibility in meeting user needs that is not available from conventional 2D geological sources. It is suggested that modelling of this type should be used by site developers and remediators to design more targeted and cost-effective site investigations and risk assessments.

\section{Introduction}

In recent years, the management of urban surface water and groundwater has attracted increasing attention as successive European Union (EU) directives and national legislation have emphasised the need to develop urban water resources in a sustainable manner. During the last century, urban groundwater was heavily exploited for industrial and public supply, but is now an under-used resource, partly because of quality issues and the perceived risk of pollution. As the demands of industry have fallen, many cities are now experiencing rising groundwater levels with consequent concerns about localised flooding of basements, reduction of soil bearing capacities under foundations, and the mobilisation of contaminants (Brassington \& Rushton 1987; Brassington 1990; Cheney \& MacDonald 1999; Heathcote \& Crompton 1997; Knipe et al. 1993; Wilkinson \& Brassington 1991; Greswell et al. 1994).

Given the potential costs of dealing with these issues, it is important that urban groundwater management is considered as an integral part of the urban planning process. Although the understanding of urban groundwater has improved in recent years, the rates of recharge and the vulnerability (Vrba \& Zoporozec 1994) of groundwater to pollution 
are often poorly constrained in conurbations underlain by complex sequences of Quaternary and artificial deposits. Understanding the architecture and hydrogeological regime of these deposits is critical to the development of an integrated surface water and groundwater catchment management strategy.

Culshaw (2005) gave a brief description of the applied use of 3D geological models in the shallow subsurface. A detailed application of this approach is given by work undertaken by the British Geological Survey (BGS) in central Manchester and Salford in collaboration with the North West Region of the Environment Agency. Using the wealth of information available from site investigation studies, an attributed geological model has been built that shows the spatial distribution, interconnectivity and inferred permeability of deposits in the shallow subsurface. The value of this approach to groundwater resource modelling is discussed, and some of the limitations that still need to be addressed are highlighted.

\section{Hydrogeological setting}

The main surface water features in the study area (Figure 1) are the rivers Irwell, Medlock, Irk, Mersey, and the Manchester Ship Canal (MSC). The MSC represents the canalised rivers Irwell and Irk through Manchester. Most of the rivers rise on high moorland to the north and east of the area and generally have gained significant flows by the time they reach the Manchester conurbation. The MSC is a significant feature of the local hydrology, receiving flows from the rivers Irwell, Medlock, and Irk. There are also a number of smaller canals such as the Bridgewater Canal. 
The Permo-Triassic sandstones beneath central Manchester and Salford form part of the Manchester and East Cheshire aquifer which provides baseflow to the rivers and is also a significant groundwater resource for both industrial and public water supply. Groundwater abstraction from the Permo-Triassic sandstone aquifer is concentrated around the industrial areas of Trafford Park and the Irwell Valley. An embargo on new groundwater abstraction licences in the Trafford Park area was first introduced by the former Mersey and Weaver River Authority in 1973 (Mersey and Weaver River Authority 1973) because of the highly reduced groundwater levels around Trafford Park and the related deteriorating quality of the groundwater (saline up-coning) in the area following decades of heavy industrial abstraction. Groundwater abstraction in the Trafford Park area between 1940 and 1960 averaged $20 \mathrm{~m}^{3} \mathrm{~d}^{-1}$ but by the 1990 s this had reduced to about $8 \mathrm{~m}^{3} \mathrm{~d}^{-1}$ (ESI 2004). As a result, since the 1960s, groundwater levels in much of the study area, including Trafford Park, have recovered significantly, although the continued abstraction of groundwater for industrial purposes has resulted in a marked pumping-induced cone of depression under Trafford Park. Elsewhere, groundwater levels have generally stabilized and are broadly similar to surface water elevations, implying that groundwater is now discharging to surface either directly or via sewers and drains.

Coal Measures sandstones crop out in the north and east of the area and are also significant water-bearing units, although the water is usually of adverse quality (Carney et al. 2001) especially when associated with former mine workings (Banwart \& Malmström 2001). Since coal mining ceased in this part of the Lancashire Coalfield in 1990, groundwater levels in the Carboniferous strata have risen rapidly. Minewater is currently discharging to the Bridgewater Canal, and is also predicted to outbreak in the 
north from the Agecroft mine unit (IMC 2000). The degree of hydraulic connection between the Coal Measures and the Permo-Triassic aquifer is not well constrained but there is the potential for poor quality water associated with the flooded mines to affect the quality of groundwater in the overlying Permo-Triassic aquifer, particularly where the units are juxtaposed by faulting. However, most recharge reaches the sandstone aquifer(s) via the complex thick superficial deposits that cover much of the region.

Despite the many studies that have been undertaken in the area (e.g. Pitman 1981; Tellam \& Lloyd 1986; Tellam et al. 1986; Stansbury 1994; Tellam 1995), there remains a level of uncertainty as to the sustainable level of abstraction in the aquifer.

Against this background, the Environment Agency has commissioned a groundwater resources investigation of the Manchester and East Cheshire aquifer unit (ESI 2004). One of the key objectives of the study was to provide a firm conceptual framework to allow quantitative water resource modelling, crucial to this was the development of a sound understanding of the potential hydrogeological pathways through the Quaternary deposits of central Manchester and, in particular, Trafford Park.

\section{Development of the 3D geological model}

The geological model of the Quaternary deposits of the district was constructed using proprietary software (GSI3D - Geological Survey and Investigation in 3-D) developed by Dr H.G. Sobisch of the University of Cologne (Hinz et al. 1999; Kessler et al. 2004) as described by Culshaw (2005).

The Manchester model (Figure 2) was built from a subset of 2000 boreholes, chosen to provide optimum areal and stratigraphical coverage of the principal Quaternary deposits. 
Surfaces were defined by 100 cross sections spaced at approximately $250 \mathrm{~m}$ intervals. The model was further constrained by modern 1:10 000 geological mapping and by a digital terrain model (DTM) with a vertical resolution of $5 \mathrm{~m}$. The main elements of the model are shown in a schematic cross-section (Figure 3) and described below.

\section{Glacigenic Deposits}

Sand and gravel (outwash deposits) of variable thickness occur at the base of the glacigenic sequence. The deposits, which fill depressions in the bedrock surface, are present beneath the Irwell valley to the west of Salford and in the buried valley system that skirts Trafford Park. The deposits are mostly overlain by till but along parts of the River Irwell where the till sheet has been eroded, they are overlain directly by younger outwash gravels.

The depositional products of the glaciation are dominated by till which covers all but the most prominent bedrock features. Typically, much of the till is a poorly-sorted, unstratified mixture of rock fragments in a matrix of stiff sandy clay. A distinction can be drawn between stiff, over-consolidated clays and softer, less consolidated clays. A series of intra-till sands have been identified within the body of the till. The till sheet thickens to over $30 \mathrm{~m}$ in the east, and is the predominant deposit in thick buried channel sequences that occur in the Trafford Park area. The impounding of meltwater during deglaciation formed transient glacial lakes in which deposits of silts and laminated clays accumulated. The most extensive laminated clays occur towards the top of the glacigenic sequence to the south and west of Trafford Park. The unit can be traced over an area of several square kilometres, and is of fairly constant thickness, around $5 \mathrm{~m}$. Thinner and less persistent clays occur within the till. Localised fine and very fine sands occur on high ground in the 
north of the area and are interpreted as glaciofluvial/lacustrine in origin, possibly laid down in standing water trapped between ice in the Manchester embayment and rising ground to the north.

Towards the end of the glacial period, meltwaters carrying sand and gravel deposited a spread of 'flood gravels' (outwash sheet deposits) across much of the Manchester embayment. Thicknesses of 4 to $5 \mathrm{~m}$ are typical, increasing to $7 \mathrm{~m}$ locally. The deposits comprise an upper unit of brown, fine to coarse-grained silty sand, with basal beds of well graded sand and gravel with occasional cobbles.

\section{Post glacial deposits}

Post-glacial (Holocene) deposits are largely confined to the modern river valleys and include river terrace deposits and tracts of alluvium. Terrace deposits are present intermittently along the river valleys of the Irwell and Medlock. The terrace deposits in the Irwell valley are about $3 \mathrm{~m}$ thick, consist of silty sand overlying sand and gravel, and are cut into till or laminated clay substrate. The River Irwell is flanked by alluvium, typically 6 to $8 \mathrm{~m}$ thick and in places forming extensive tracts, up to $700 \mathrm{~m}$ wide particularly in the meander belts around Salford Quays and at the western margin of the area. In the intervening tracts the river is incised in bedrock and the alluvium is poorly developed. The alluvium typically comprises an upper layer of soft grey silty clay (overbank deposits), underlain by several metres of coarse sand or gravelly sand and gravel (river channel deposits). An area of lowland peat, known as Trafford Moss, lies beneath Trafford Park Industrial Estate. Although formerly extensive, the construction of the Trafford Park industrial complex has led to much of it being removed. 


\section{Anthropogenic deposits}

The legacy of Manchester and Salford's industrial past is a widespread cover of artificial deposits, which are extremely variable in terms of their composition, thickness and geometry. The classification of these deposits is problematical but one approach to dealing with this variability is to identify geographical areas where similar land use processes have operated. For example, the practice of tipping colliery waste and ash into river valleys was commonplace, and occurred widely in the Medlock valley in the Phillips Park area of Bradford. Other river valleys including the Irk, the Irwell and Bent Lanes Brook suffered similar fates, with artificial deposits raising the valley floors above the natural alluvium. By combining this information with surface mapping and downhole data, it has proved possible to identify nine areas with significant and identifiable types of artificial ground. Anthropogenic zoning provides a first step in assessing the likely sources of diffuse groundwater pollution from former contaminative industries. Not all areas lend themselves to this approach, and it is recognised that in some parts of the conurbation, typically where numerous phases of demolition and redevelopment have taken place, precise classification is impractical.

\section{Hydrogeology of the superficial deposits}

In common with many urban areas in the UK, Manchester has no systematic shallow groundwater monitoring programme. It was, therefore, not possible to define, with any reliance, groundwater flow regimes within the superficial deposits. The performance of the system has had to be judged on a purely qualitative basis using the geological model 
and published hydrogeological property data to assess the lithological combinations most likely to permit recharge.

Estimates of permeability of each of the modelled units were derived by comparing lithological descriptions and particle size data, with published permeability values (Brassington 1998; Todd 1980; Allen et al. 1997). The deposits were accordingly classified as either permeable or weakly permeable (Table 1). Made ground is ubiquitous in its distribution and highly heterogeneous but for modelling purposes is here regarded as permeable in the absence of acknowledged data to the contrary.

\section{Hydrogeological domain mapping}

The hydrogeological performance of the sequence can be inferred from knowledge of the thickness, extent and inferred permeability of the constituent lithologies. Sediment assemblages dominated by permeable units are mainly granular and are likely to support vertical and horizontal flow, whereas those that are clay and silt-rich (weakly permeable) are more likely to inhibit flow. By defining sediment associations and mapping their occurrences throughout the model the likely hydrogeological performance of different arrangements of sediment can be estimated. The approach follows that of domain mapping, pioneered by McMillan et al. (2000), and now well established, particularly at catchment scale or larger, for analysing Quaternary sequences. In the Manchester conurbation, seven domains have been defined (Table 2, Figure 4), which are distinguished using a rules base that takes account of the following factors:

- The nature of the underlying bedrock (major, minor or non aquifer) 
- The stacking arrangement in vertical profile of units of differing inferred permeability, as defined in Table 1.

- The position in the sequence and thickness of any weakly permeable units

[Deposits over $5 \mathrm{~m}$ thick are considered a barrier to vertical water flow. Those less than $5 \mathrm{~m}$ thick are classified as permeable due to the potential effects of weathering and fracturing.]

- The potential for perched groundwater to occur above weakly permeable deposits.

The resulting hydrogeological domain map (Figure 5) gives a visual assessment of the areas where superficial deposits with similar intrinsic properties exist. By ranking the domains in terms of their inferred permeability (high, medium, low), as shown in Table 3, an indication is given of the recharge potential of the bedrock aquifer (Figure 6).

Sites favourable for recharge occur in the north-west on rockhead highs, and along the river valleys of the Irwell and Medlock where there is either a thin covering of superficial deposits, or the superficial deposits comprise coarse, permeable materials. The MSC is in direct hydraulic contact with the Permo-Triassic sandstone between Salford and Eccles; further west, thickening till intervenes between the base of the canal and the underlying aquifer. It is likely that the aquifer is recharged by, or discharges to, the MSC except where the canal base is excessively silted, or where it may have been engineered to reduce leakage.

\section{Effects of surface sealing}


A common factor associated with the development of urban areas is the impermeabilisation of a significant proportion of the land surface (Foster et al. 1993). This impermeabilisation, here termed surface sealing, can significantly reduce the amount of water available for direct recharge to the bedrock aquifer depending on the type and degree of sealing. Rainfall on impervious surfaces, such as roofs, roads, and other structures evaporates directly, contributes to surface run-off, or drains into storm sewers or soakaways. Recharge in this situation will be minimal, except where point/line recharge can occur through soakaways or as a result of leakage from storm sewers or mains. In urban areas, it has been estimated that rates of leakage of 20 - $50 \%$ from water mains are common (Lerner 2002) and that a combination of leakage from services may balance losses due to surface sealing (Lerner 2002). However, a combination of service leakage and surface sealing will impact on the distribution of recharge in an urban environment.

The degree of surface sealing can be measured using remote sensing techniques, topographic maps or land use data combined with field observations. In central Manchester and Salford, a combination of these methods was employed to produce a surface sealing classification at a resolution of about 1:10 000 scale. The ground ranges from relatively permeable across recreational areas and on the floodplain (0-49 \% sealed) to virtually impervious in the main industrial areas, along major roads (80-100 \% sealed). This data layer can be incorporated in the recharge model according to the matrix detailed in Table 4 to give an indication of the impact of surface sealing on direct groundwater recharge to the sandstone aquifer (Figure 7). It is apparent that moderate to highly impervious materials cover a large proportion of the study area and that this is likely to 
significantly reduce recharge potential. This may be offset by additional recharge through mains leakage, excess irrigation, septic tanks, and sewer system leakage. Direct natural recharge in Trafford Park and central Manchester is likely to be very low as the areas are largely sealed. Any recharge that may occur is likely to be indirect and controlled by the underlying network of pipes, drains, and localised pervious areas. The areas where most direct recharge can be expected are along the main river valleys and in more open residential areas of Salford to the north of the MSC, where the aquifer is at outcrop or in hydraulic continuity with surface water.

\section{Limitations of methodology and validity of assumptions}

The methodologies employed in the development of this conceptual model are subject to a number of limitations:

\section{Data coverage}

The integrity of the geological model depends on having an array of accurately logged boreholes at sufficient density to allow geological units to be mapped out with confidence. In practice older built up areas of the city are generally poorly represented in the borehole database. Also in areas of thicker superficial deposits, fewer boreholes penetrate the full sequence.

\section{Geological complexity}

The regional scale of the model makes it difficult to accommodate the detailed variation commonly found in closely spaced boreholes. This is particularly true of the glacigenic 
deposits where beds are often laterally persistent and lithological variation can only be represented in general terms. The heterogeneity of the deposits is a related problem, particularly with regard to till, and it is conceivable that unidentified preferential flow paths could exist in otherwise weakly permeable deposits.

\section{Hydrogeological properties}

The hydraulic conductivity values assigned to each of the modelled units are based on published information and need to be validated by in-field measurement, laboratory testing, or use of geotechnical and site investigation reports. Similarly, the assumption that below $5 \mathrm{~m}$ thickness the aquicludes are likely to be permeable would be better based on site specific testing.

\section{Groundwater and head gradients}

Quantification of recharge needs to take account of vertical head gradients between the bedrock aquifer and saturated permeable deposits in the Quaternary sequence and surface watercourses, since these, as well as permeability, control the amount of actual recharge

and discharge. It is for this reason that the model output layer is referred to as 'potential recharge'. This 'head dependency' needs to taken into account in assessing resource availability, however, attempts to use first-strike data from boreholes in the Manchester area were insufficient to create piezometric contours or identify perched groundwater (Robins et al. 2003). It is likely to be prohibitively expensive to establish and maintain a widespread temporal and spatial groundwater level monitoring in the superficial deposits. It may be possible to utilise groundwater elevation information from site investigation 
reports, although this is generally for small site areas only and unlikely to yield temporal data. As mentioned previously, leaking water mains and sewers are recognised as being important controls on groundwater levels in the shallow (Quaternary) deposits. It is conceivable that incorporating sewers and water mains, including invert levels and leakage rates as recorded by the water utilities, as additional layers in the 3D superficial deposits model would enhance the value to catchment-scale groundwater resource assessment.

\section{Application of model for groundwater resource management}

Understanding the complexity and spatial variability of the Quaternary deposits of the study area, is critical to local water resources management. On a regional scale the detail provided by the Manchester model has application in the development of catchment abstraction management strategies (CAMS) (Environment Agency 2002) as currently being developed by the Environment Agency. Central to these strategies is the need to establish a sustainable balance between recharge and groundwater abstraction. Key stages in this process are:

- The formulation of credible, quantified conceptual model of the sandstone aquifer and its hydrogeological relationship with surface watercourses.

- Calculating preliminary water balances between inputs and outputs from the groundwater system. These include rainfall recharge, lateral inflows from adjacent aquifer units, and leakage from or to surface watercourses. 
- Investigative numerical modelling of the aquifer system (ranging from vertical slice through to spatially distributed transient modelling) to test the conceptual model and assess different abstraction scenarios.

The Environment Agency has utilised the bespoke outputs from the 3D geological model to provide a better understanding of recharge areas and a more informed basis for water balance calculations (ESI 2006). The geological relationships identified in the 3D model were tested at site scale by incorporating groundwater flow directions and piezometric heads in the superficial deposits, obtained from contaminated land investigations at a number of sites in Trafford Park (ESI 2006). This has improved the conceptual understanding of groundwater flow in the superficial deposits and the interaction with surface watercourses.

GIS layer outputs of the hydrogeological domains, combined with water main and sewer elevations and leakage estimates provided by the water utility company, allowed scoping calculation to be made of recharge from, and discharge to, these services under different groundwater abstraction and head scenarios.

It is envisaged that the geological model could be used to provide a context to evaluate contaminated land or potentially polluting activities at a site-scale.

\section{Summary and conclusions}

A 3D geological model of the superficial deposits beneath Manchester and Salford has been constructed based primarily on borehole information. The model provides detailed information on the 3-dimensional architecture and physical attributes of the complex 
glacigenic and post-glacial sediments that underlie the central part of the conurbation. The model has been designed to support a range of thematic products relevant to sustainable development, but its principal use to date has been in the area of groundwater management.

A conceptual recharge model has been developed in collaboration with the Environment Agency for the area centred on Trafford Park. This has subsequently been used to form the basis of a site scale numerical groundwater model developed by ESI Ltd (2006). The findings of the study will underpin development of a sustainable groundwater abstraction strategy in an area where over-abstraction for industrial purposes was once a serious problem.

The 3D geological model and related thematic outputs set the context for assessing pollution threats to the sandstone aquifer from the numerous historic contaminative land uses in and around Trafford Park. The aquifer vulnerability can be correlated directly to the groundwater recharge mechanisms as most contaminants are transported in the aqueous phase as part of the recharge process (Foster 1998).

The scale of the model (about 1:10 000) means that it could be used by site developers and remediators to design more informed, targeted and cost-effective site investigations and risk assessments.

Access to, and use of, 3D geological models of the shallow sub-surface is currently limited but there is increasing recognition among users of the added value offered by acquiring information in $3 \mathrm{D}$ rather than $2 \mathrm{D}$. The challenge is to make the models available at an early stage in the urban regeneration process so that they may better inform strategic planning options, ground investigation and reclamation strategies. This is 
reliant on the models being appropriate in terms of content and scale, and that inherent uncertainties associated with the model are appropriately quantified.

\section{Acknowledgments}

We wish to thank the Environment Agency and ESI Ltd for supplying information and comment on their use of the 3D geological model for recharge modelling and water resource management. This paper is published with the permission of the Executive Director of the British Geological Survey (NERC). 


\section{References}

Allen, D. J., Brewerton, L. J., Coleby, L. M., GibBs, B. R., Lewis, M. A., MacDonald, A. M., Wagstaff, S. J. \& Williams, A. T. 1997. The physical properties of major aquifers in England and Wales. British Geological Survey Technical Report WDI97/24. Environment Agency R\&D Publication 8.

BANWART, S. A. \& MALMSTRÖM, M. E. 2001. Hydrochemical modelling for preliminary assessment of minewater pollution. Journal of Geochemical Exploration, 74, 73-97.

Brassington, R. 1998. Field Hydrogeology. John Wiley \& sons. $2^{\text {nd }}$ edition.

Brassington, F. C. \& Rushton, K. R. 1987. A rising water table in central Liverpool. Quarterley Journal of Engineering Geology, 20, 151-158.

Brassington, F. C. 1990. Rising groundwater levels in the United Kingdom. Proceedings of the Institution of Civil Engineering, 88, 1, 1037-1057.

Carney, J. N., Ambrose, K. \& Brandon, A. 2001. Geology of the country between Loughborough, Burton and Derby. Sheet description of the British Geological Survey, 1:50 000 Series Sheet 141 Loughborough.

Cheney, C. S. \& MACDonald, A. M. 1999. Groundwater responses to urbanisation and changing patterns of industrial development in the Wigan metropolitan area, north west 
England. In: ChiLton, P. J. (ed) Groundwater in the Urban Environment: Selected City Profiles. Volume 21 of the International Contributions to Hydrogeology.

Culshaw, M. G. 2005. From concept towards reality: developing the attributed 3D geological model of the shallow subsurface. Quarterly Journal of Engineering Geology and Hydrogeology, 38, 231-284.

EnVIRONMENT AGENCY. 2002. Managing water abstraction: The Catchment Abstraction Management Strategy process. Environment Agency Publication.

ESI Ltd. 2004. Manchester and East Cheshire Water Resources Study: Phases 1 \& 2, Final Report (prepared for the Environment Agency).

ESI Ltd. 2006. Manchester and East Cheshire Water Resources Study: Phase 3, Trafford Park Final Report (Prepared for the Environment Agency).

Foster, S. S. D. 1998. Groundwater recharge and pollution vulnerability of British aquifers: a critical overview. In: RoBINS, N. S. (ed.) Groundwater Pollution, Aquifer Recharge and Vulnerability. Geological Society, London, Special Publications, 130, 722. 
Foster, S. S. D., Morris, B. L. \& Lawrence, A. R. 1993. Effects of urbanisation on groundwater recharge. International Conference on groundwater problems in urban areas. Institution of Civil Engineers, London.

GResweLl, R. B., LLOYD, J. W., LeRneR, D. N. \& KNIPE, C. V. 1994. Rising groundwater in the Birmingham area. In: WiLKINSON, W. B. (ed). Groundwater problems in urban areas. Proc. Conf. Institution of Civil Engineers, June 1993, 64-75, discussion 355-368.

HeAthCote, J. A. \& CROMPTON, D. M. 1997. Managing the impact of urban groundwater rise. In: Chilton, P. J. (ed) Groundwater in the Urban Environment: Problems, Processes and Management. International Association of Hydrogeologists XXVII Congress.

Hinze, C., SoBisch, H-G. \& Voss, H-H. 1999. Spatial modelling in Geology and its practical use. Mathematische Geologie, 4, 51-60.

IMC Consulting Engineers. 2000. South Lancashire coalfield closure minewater rebound study: Phase 3, Agecroft minewater unit (prepared for the Environment Agency).

Kessler, H., Mathers, S J. \& Sobisch, H-G. 2004. GSI3D - The software and methodology to build near-surface 3-D geological models. BGS Internal Report. IR/04/029. 
Knipe, C. V., Lloyd, J. W., LeRneR, D. N. \& GRESWeLl, R. 1993. Rising groundwater levels in Birmingham and the engineering implications. Construction Industry research and Information Association (CIRIA) Special Publication 92.

LERNER, D. N. 2002. Identifying and quantifying urban recharge: a review. Hydrogeology Journal, 10, 143-152.

MerSey AND WEAVER RIVER AUtHORITy. 1973. Statement of Policy for Ground-Water Management.

McMillan, A. A., Heathcote, J. A., Klinck, B. A., Shepley, M. G., Jackson, C. P. \& Degnan, P. J. 2000. Hydrogeological characterisation of the onshore Quaternary sediments at Sellafield using the concept of domains. Quarterly Journal of Engineering Geology and Hydrogeology, 33, 301-323.

Pitman, G. T. K. 1981. The hydrogeology of the Permo-Triassic of the Greater Manchester Region. Unpublished PhD Thesis, University of London.

Robins, N. S., Forster, A., Lewis, M. A. \& Butcher, A. S. 2003. Shallow and perched groundwater hazards and hazard mapping in the United Kingdom. In: Aquifer Vulnerability and Risk. Proceedings of the First International Workshop on Aquifer Vulnerability and Risk. 
STANSBURY, M. 1994. An assessment of the groundwater levels and groundwater quality at Trafford Park, Manchester. Unpublished MSc Thesis, University of Birmingham.

Tellam, J. H. \& Lloyd, J. W. 1986. Problems in the recognition of seawater intrusion by chemical means: an example of apparent chemical equivalence. Quarterly Journal of Engineering Geology, 19, 389-398.

Tellam J. H., Lloyd, J. W. \& Walters, M. 1986. The morphology of a saline groundwater body: its investigation, description and possible explanation. Journal of Hydrology, 83, 1-21.

Tellam, J. H. 1995. Hydrochemistry of the saline groundwaters of the Lower Mersey Basin Permo-Triassic sandstone aquifer. Journal of Hydrology, 165, 45-84.

ToDD, D. K. 1980. Groundwater Hydrology. John Wiley \& Sons. $2^{\text {nd }}$ edition.

VRBA, J. \& ZoporozeC, A. 1994. Guidebook on Mapping Groundwater Vulnerability. International Contributions to Hydrogeology, 16, 119.

Wilkinson, W. B. \& Brassington, F. C. 1991. Rising groundwater levels - an international problem. In: Downing, R. A. \& Wilkinson, W. B (eds) Applied Groundwater Hydrology, a British perspective, 36-53. 
Table 1: Inferred permeability of superficial deposits

\begin{tabular}{|l|l|l|}
\hline \multicolumn{1}{|c|}{ Superficial Deposit } & \multicolumn{1}{|c|}{ Lithology } & \multicolumn{1}{c|}{ Inferred permeability } \\
\hline Made ground & $\begin{array}{l}\text { Anthropogenic material and re- } \\
\text { worked natural deposits }\end{array}$ & Permeable \\
\hline Alluvial overbank deposits & Silt, clay, peat & Weakly permeable \\
\hline $\begin{array}{l}\text { Alluvial river channel } \\
\text { deposits }\end{array}$ & Sand, gravel, peat & Permeable \\
\hline River terrace deposits & $\begin{array}{l}\text { Sand, gravel, possible clayey in } \\
\text { upper part }\end{array}$ & Permeable \\
\hline Outwash sheet deposits & Silty sand on clayey sand \& gravel & Permeable \\
\hline Glaciolacustrine deposits & Laminated silt and clay & Weakly permeable \\
\hline $\begin{array}{l}\text { Glaciolacustrine sands and } \\
\text { silts }\end{array}$ & Fine sand overlying laminated silt & Permeable \\
\hline Till deposits & $\begin{array}{l}\text { Till, interbedded sand, impersistent } \\
\text { laminated clay }\end{array}$ & $\begin{array}{l}\text { Weakly permeable with possible } \\
\text { intermittent permeable horizons }\end{array}$ \\
\hline $\begin{array}{l}\text { Basal sand and gravel } \\
\text { deposits }\end{array}$ & Clayey sand \& gravel & Permeable \\
\hline
\end{tabular}


Table 2: Hydrogeological domain classification

\begin{tabular}{|c|c|c|c|c|}
\hline Group & \multicolumn{2}{|r|}{ Domain } & \multirow{2}{*}{$\frac{\text { Figure } 5}{\mathrm{~A}}$} & \multirow{2}{*}{$\begin{array}{l}\text { Lithologies/geo-morphological units } \\
\text { Permo-Triassic sandstone. }\end{array}$} \\
\hline \multirow{2}{*}{ Major aquifer } & 1 & At outcrop & & \\
\hline & 2 & $\begin{array}{l}\text { Permeable superficial } \\
\text { deposit on a major } \\
\text { aquifer }\end{array}$ & B & $\begin{array}{l}\text { Single or multiple layers of: river } \\
\text { channel, river terrace, outwash sheet, } \\
\text { basal gravel, and glaciolacustrine sand } \\
\text { and silt deposits. }\end{array}$ \\
\hline \multirow[t]{2}{*}{ Minor aquifer } & 3 & At outcrop & A & Coal Measures sandstones. \\
\hline & 4 & $\begin{array}{l}\text { Permeable superficial } \\
\text { deposit on a minor } \\
\text { aquifer }\end{array}$ & B & $\begin{array}{l}\text { Single or multiple layers of: river } \\
\text { terrace, outwash sheet, basal gravel, and } \\
\text { glaciolacustrine sand and silt deposits. }\end{array}$ \\
\hline $\begin{array}{l}\text { Potential } \\
\text { perched aquifer }\end{array}$ & 5 & $\begin{array}{l}\text { Perched superficial } \\
\text { deposit }\end{array}$ & $\mathrm{C}$ & $\begin{array}{l}\text { River channel, river terrace, outwash } \\
\text { sheet, glaciolacustrine sand and silt } \\
\text { deposits overlying }>5 \mathrm{~m} \text { till, } \\
\text { glaciolacustrine clay, river overbank } \\
\text { deposits or Manchester Marls (non- } \\
\text { aquifer). }\end{array}$ \\
\hline Aquitard & 6 & $\begin{array}{l}\text { Weakly permeable } \\
\text { superficial deposit }\end{array}$ & $\mathrm{D}$ & $\begin{array}{l}>5 \mathrm{~m} \text { till, glaciolacustrine clay, or river } \\
\text { overbank deposits. }\end{array}$ \\
\hline Non-aquifer & 7 & Non-aquifer bedrock & $\bar{A}$ & Manchester Marls Formation. \\
\hline
\end{tabular}


Table 3: Potential recharge rating based on hydrogeological domains

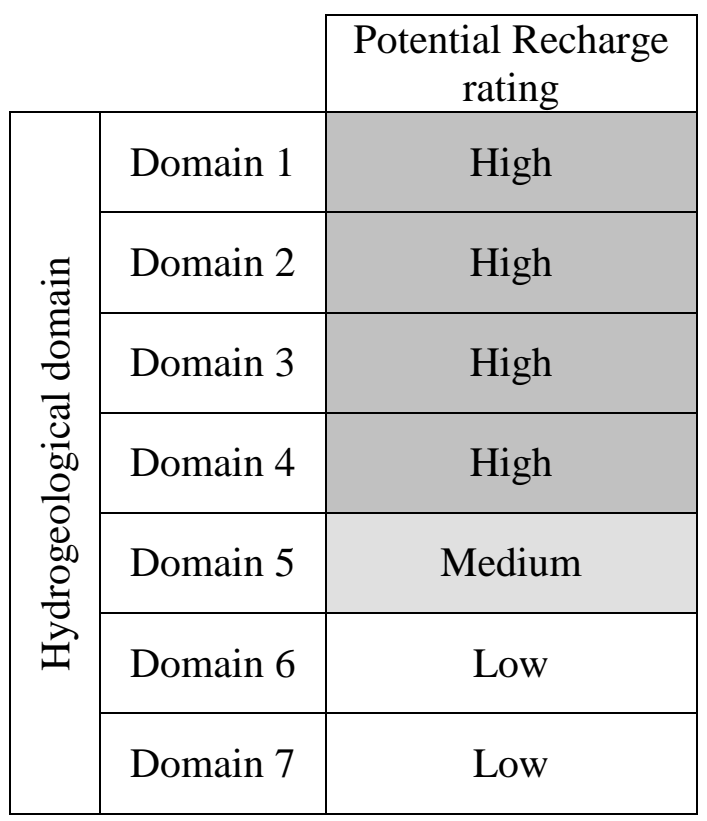


Table 4: Impact of Surface Sealing on direct groundwater recharge

\begin{tabular}{|c|c|c|c|c|}
\hline & \multicolumn{3}{|c|}{ Percentage of surface sealing } \\
\hline & & $0-49$ & $50-79$ & $80-100$ \\
\hline \multirow{3}{*}{ 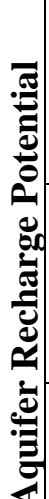 } & $\stackrel{50}{00}$ & High & High & Medium \\
\hline & 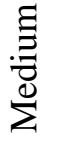 & Medium & Medium & Low \\
\hline & 艿 & Low & Low & Low \\
\hline & & & & \\
\hline
\end{tabular}

Lelliott, M., Bridge, D., Kessler, H., Price, S., Seymour, K 


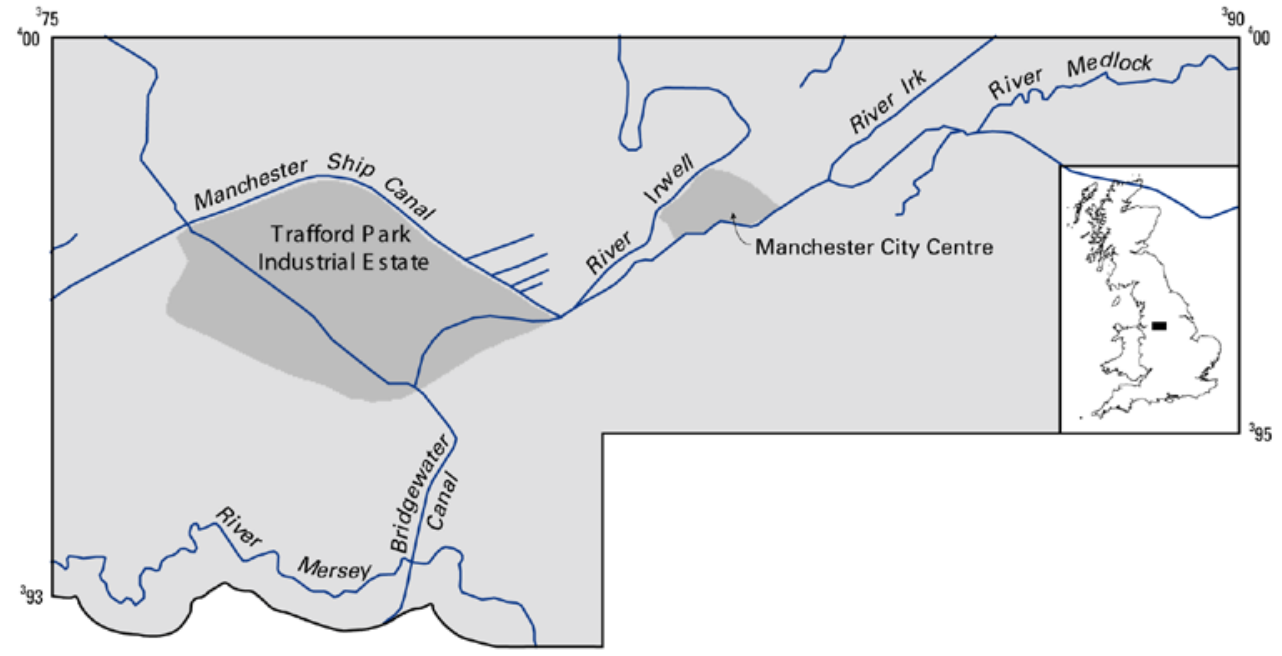

Figure 1: Project area location map

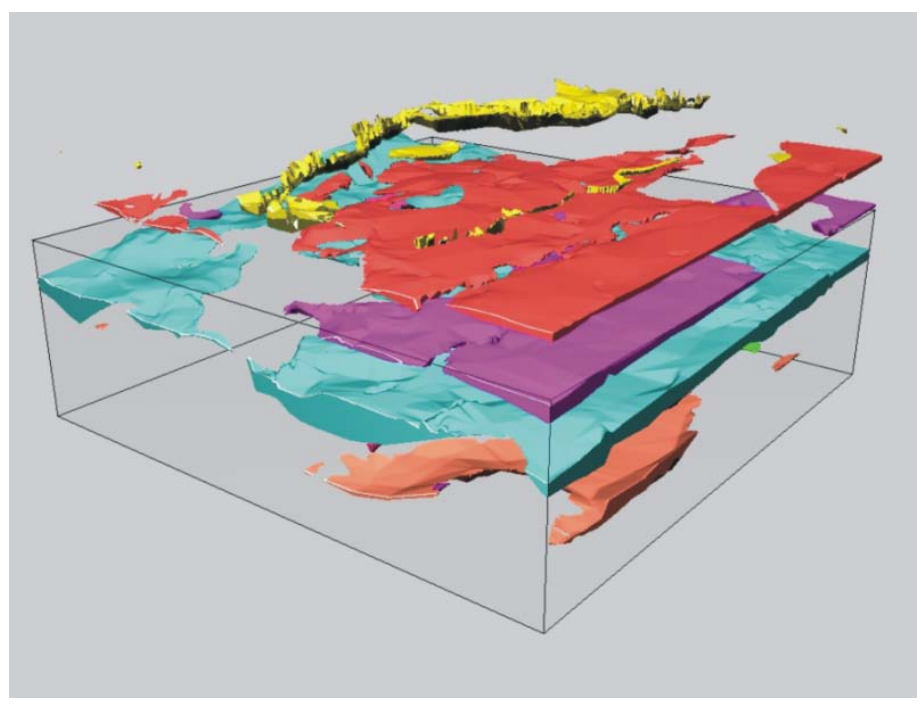

Figure 2: 3D geological block model of Trafford Park and Eccles. 

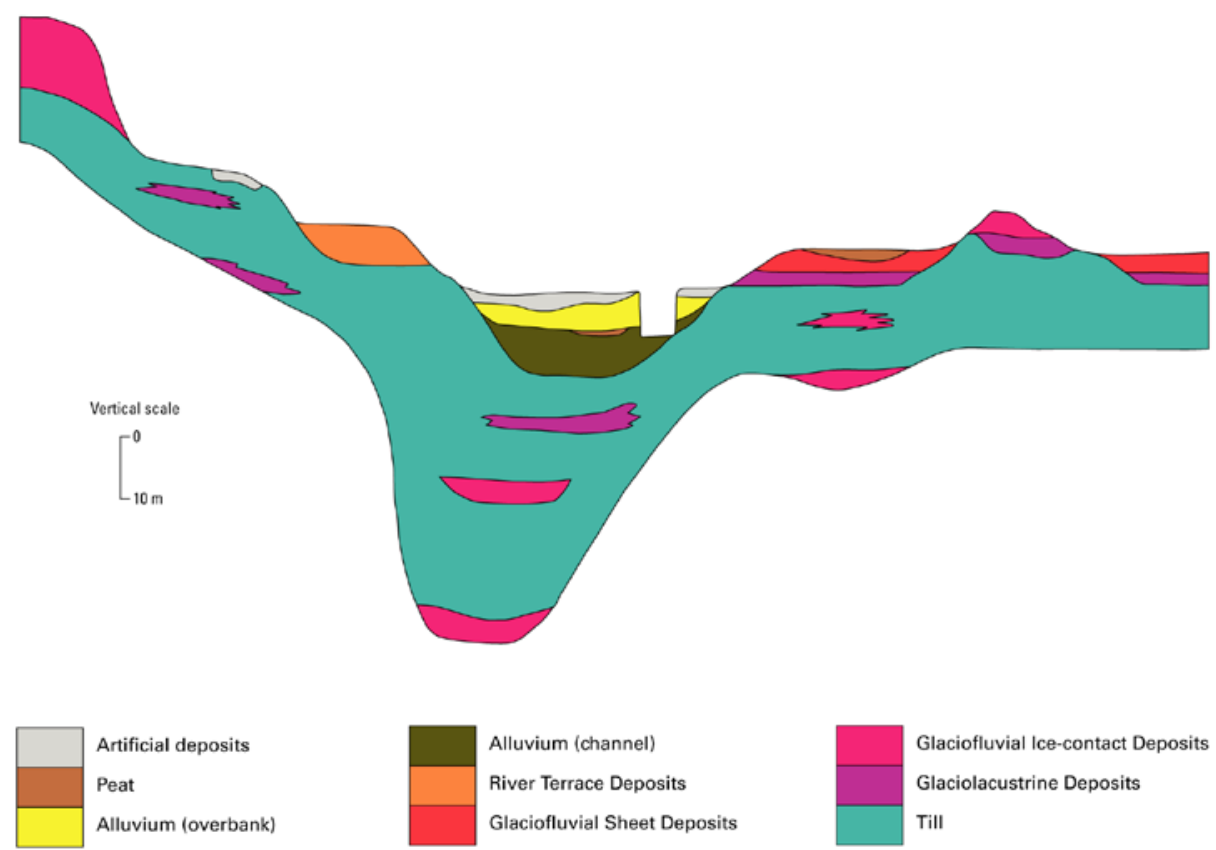

Figure 3: Schematic diagram (with vertical exaggeration) showing relationships between modelled units for central Manchester and Salford. (Adapted from Culshaw, 2005).

Lelliott, M., Bridge, D., Kessler, H., Price, S., Seymour, K 
A

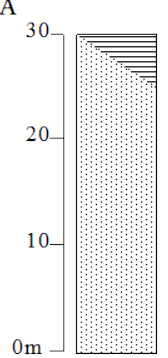

Bedrock at outcrop or covered by a

maximum of 5 metres weakly

permeable deposits. Domain defined by

underlying bedrock aquifer.

\begin{tabular}{|c|c|c|}
\hline \multicolumn{3}{|c|}{ Underlying bedrock aquifer } \\
\hline Major & Minor & Non \\
\hline Domain 1 & Domain 3 & Domain 7 \\
\hline
\end{tabular}

B

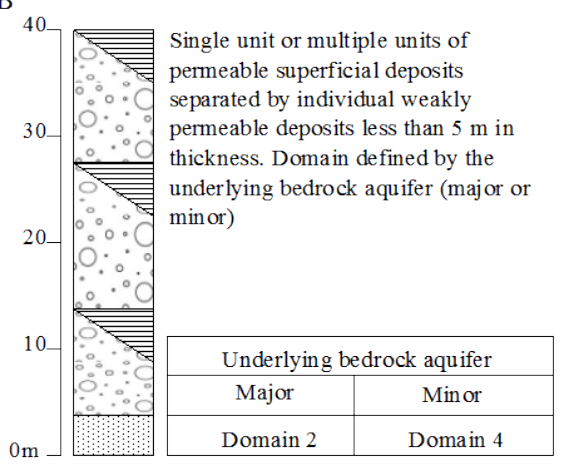

C

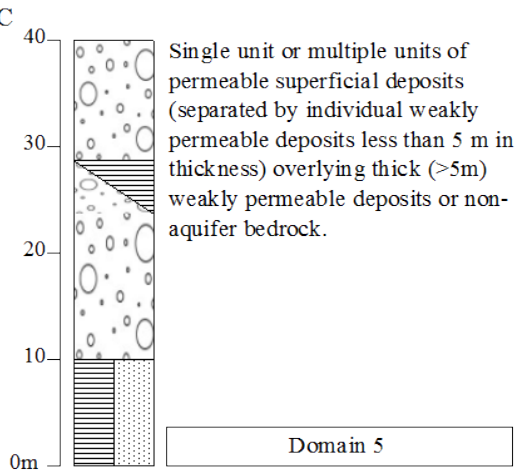

$\mathrm{D}$

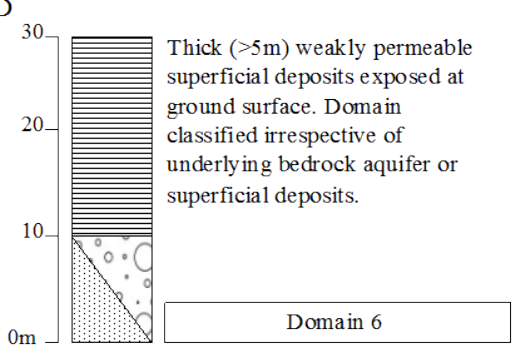

Permeable superficial deposit

Figure 4: Schematic hydrogeological domain classification (for use in conjunction with Table 2) 


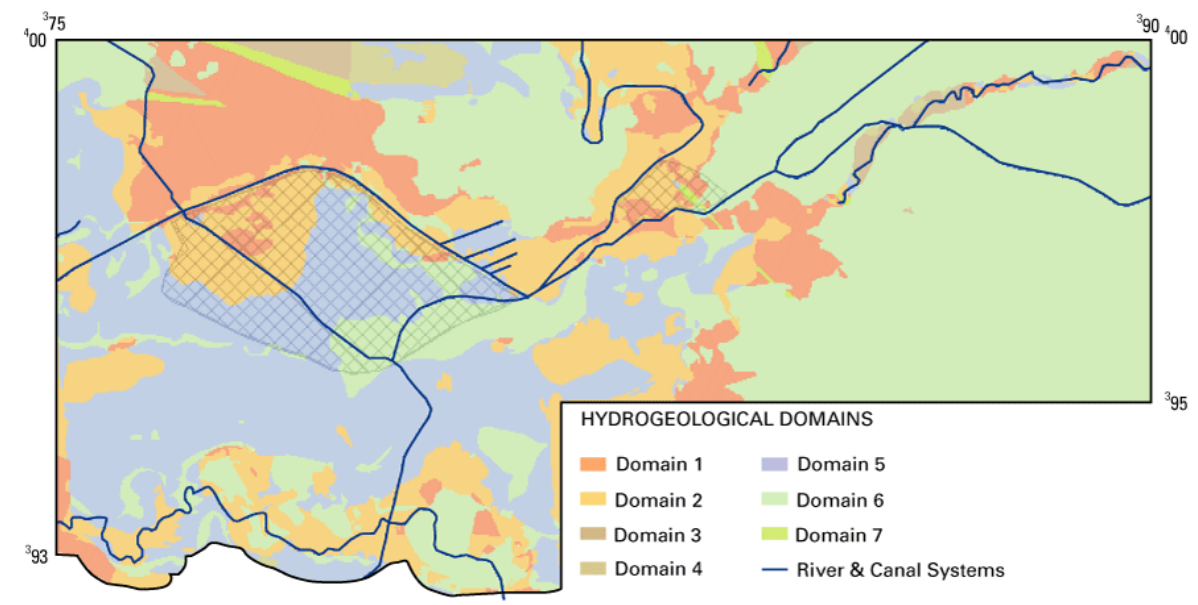

Figure 5: Hydrogeological domains derived for the Manchester project area

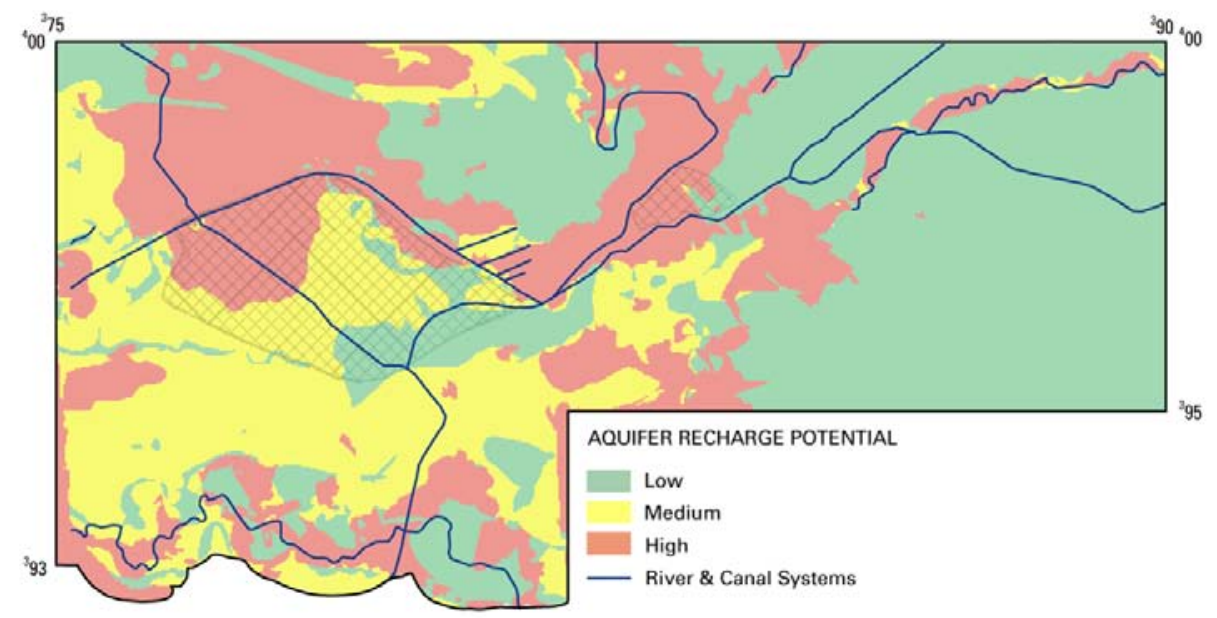

Figure 6: Aquifer recharge potential derived from hydrogeological domains.

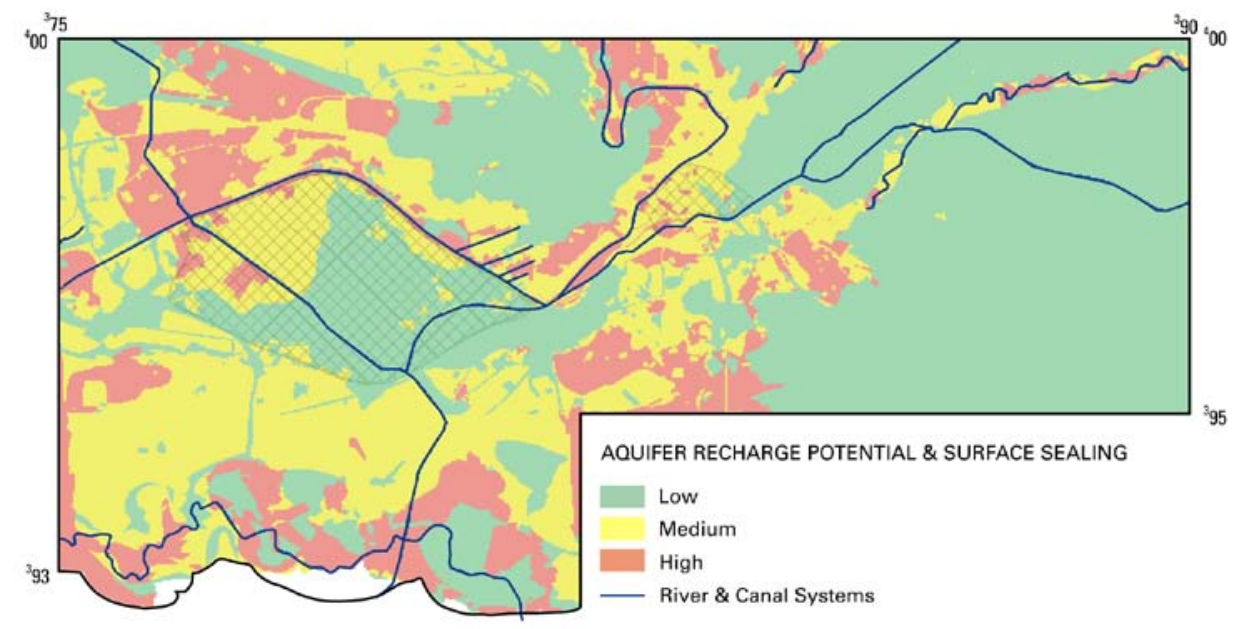

Figure 7: Impact of surface sealing on aquifer recharge potential 